
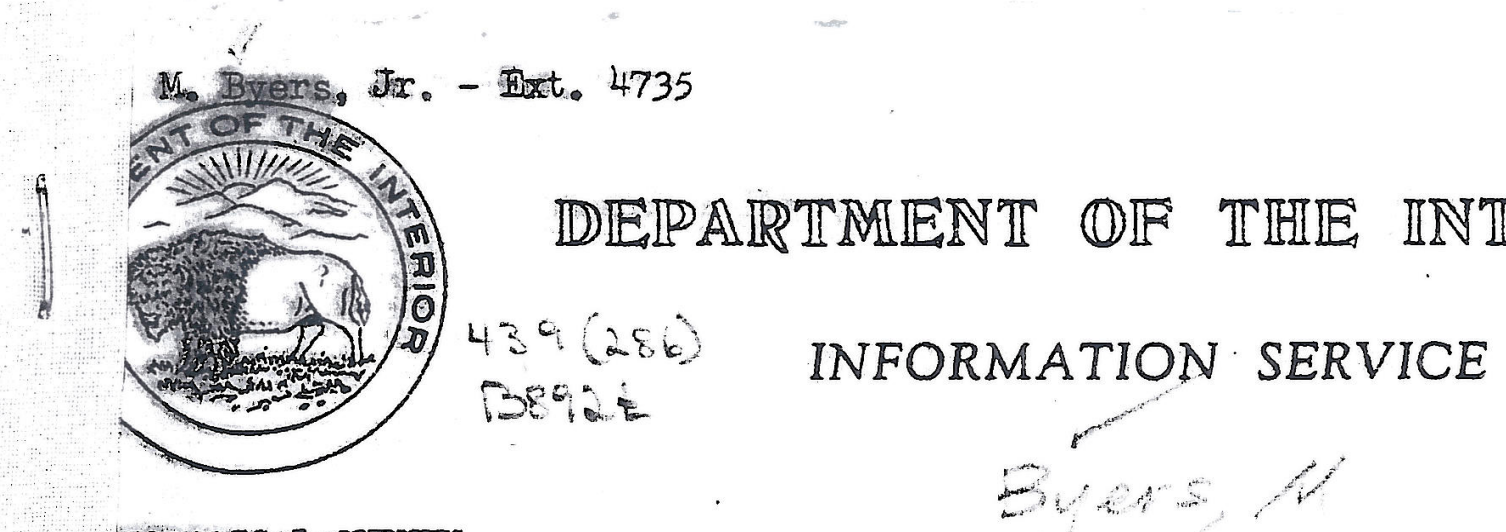

BOTOGICAI SURVEI

Por release February 12,1945

TUNGSTEN DEPOSITS OF THE FYDER DISTRICT, SOUTHEASTERT ATASTKA

A preliminary report on the tungsten deposits of the Fyder district, southeastern Alaska, has been prepared by the Geological Survey, according to a state-

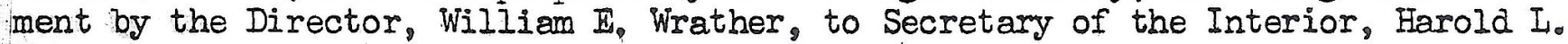
Ickes.

The Hyder district is largely in the Salmon River drainage basin at the lead of Portland Canal, southeastern Alaska. The area was examined by the Geological Survey during the period June 3, 1942, to February 6, 1943.

The scheelite-bearing bodies are mineralized shoots in quartz veins that occur in granodiorite and in inclusions of metamorphic rocks in the granodiorite. Most of the veins strike $N_{0} 40^{\circ} \mathrm{W}$. to $\mathbb{N}_{0} 60^{\circ} \mathrm{W}$ and dip $50^{\circ}$ to $80^{\circ} \mathrm{NE}$. In places the scheelite-bearing veins are as much as 7 feet thick. The principal gangue mineral is quartz, with lesser amounts of calcite, ankerite, and barite, Galena and pyrite are present in nearly all veins, and some veins contain other sulfide minerals and native gold.

Only two mines in the Hyder district are known to contain scheelite-bearing rock in sufficient quantity and of sufficiently high grade to constitute ore reserves. The Riverside mine is estimated to contain about 9,000 tons of indicated ore averaging about I percent of $\mathrm{WO}_{3}$. The Mountain View mine is estimated to contain about 600 tons of indicated ore of similar grade, In addition to this indicated ore, reserves of inferred ore are present in both the Riverside and Mountain View mines.

A limited number of mimeographed copies of the report are available to those directly interested and may be obtained upon application to the Director. Geological Survey, Washington 25, D. C, 
SUPERSEDED lig Ball ray. F

\author{
UNITED STATHS \\ DEPARIMENT OF THE' INTERIOR \\ Geological Survey \\ washington
}

TUNGSTEN DEPOSITS OF THE HYDER DISTRICT, SOUTHEASTERN AJASKA

By

F. M. Byers, Jr.

\title{
INTRODUCTION
}

The Fyder district (see fig. 1) is largely in the Salmon River drainage basin at the head of Portland Canal in southeastern Alaska. The district has $22 \mathrm{miles}$ of graded gravel road, connecting with roads in British Columbia to the town of Premier and Stewart, both within 2 miles of the International Boundary. Premier is 13 miles by road north of Hyder. Stewart; with a population of about 150 in 1943, has adequate dock facilities within I mile of Hyder. In 1943 Hyder had. about 60 inhabitants.

Nany claims and groups of claims have been located in the part of the Hyder district known to contain tungsten: deposits and some of them are shown on figure 2 .

The writer worked in the district from June 3, 1942, to February 6, 1943. He was assisted by H. R. Gault until JuIy 1, 1942, and by Clyde Wahrhaftig from August 12 to December 4, 1942. From October 27, 1942, to February 6, 1943, "the' Sureau of Mines diamond-drilled, sampled, and drove an exploratory raise at the Riverside mine, and sampled the Mountain View mine. In the sumer of 1944 the Bureau of Mines extended to the. northwest the Skookum tomel drift in the Mountain View mine, and on October 1, 1944 it hed been extended for 130 feet to the position shown on figure 6 .

\section{GENERAI GEOIOGY}

A comprehensive report on the general geology of: the Hyder district was prepared by Buddington I/ and published in 1929. From that report - many of the general statements regarding the geology have been"abstracted.

1/ Buddington A.. F, , Geology of. Hyder and vicinity, southeastern Alaska: U. S. Geol. Survey Bul1. 807, 1929. 
The oldest rocks of the district comprise the Hazelton group, of probable Jurassic age, and include greenstone, tuff, volcanic breccia, graywacke, slate, argillite, and quartzite. These rocks crop out abundantly between Salmon River and the International Boundary. The Hazelton rocks in general strike west, but many exceptions to this general strike are seen, particularly near intrusive bodies.

The Helton rocks are intruded by plutonic rocks of the Coast Pange batholith. The Texas Creek granodiorite, a small batholith confined chiefly to the central portion of the district, is the oldest of the several coast Fange intrusives in the district and is intimately and probably genetically related to most of the significant mineral deposits. flongate bodies of sheared Hazelton greenstone schist and argillite, up to at least 100 feet wide and 2,000 feet long, are included. in the Texas Creek granodiorite. The largest known of these inclusions comprises the Lindeborg shear zone at the Riverside mine.

Younger Coast Range intrusives include the Hyder quartz monzonite and the Boundary granodiorite: Granodiorite porphyry dikes, 10 to: 1,000 feet wide and related to the Hyder. quartz monzonite, intrude the Texas Creek granodiorite and cut some of the scheelite-bearing veins: Dikes of granite aplite, granite pegmatite, malchite, and lamprophyre cut all the batholithic intrusives, the rocks of the Helton group, and the veins.

Veins and dikes are displaced by faults, such as the two faults followed roughly by Fish and Skookum creeks (see fig. 2 ). These two faults dip steeply westward and show zones of gouge and breccia as mach as 30 feet wide.

\section{TUNGSTEN DHPOSIMS}

Most of the scheelite known in the Hyder district is on the east side of the valley of Salmon. River in an area about $1 \frac{1}{2}$ miles wide and 3 miles long, beginning $5 \frac{1}{2}$ miles north of Hyder (see fig. 2). Scheelite is known in abundance on only two properties in this area - the Riverside and the Mountain View.

The scheelite-bearing bodies are mineralized shoots in quartz veins which cut Texas Creek granodiorite and inclusions of Hazelton rocks in the granodiorite. Most of the veins strike N. $40^{\circ}-60^{\circ} \mathrm{W}$. and dip $50^{\circ}$ to $80^{\circ} \mathrm{NE}$. The veins, therefore, are at an angle to the gneissic banding of the Texas Creek granodiorite, which in general strikes $\mathbb{N} .85^{\circ}$ E. and dips steeply northward. The scheelite-bearing veins are as much as 7 feet thick.

The ore minerals include scheelite, galena, pyrite, tetrahedrite, pyrrhotite, chalcopyrite, sphalerite, and native gold. Calena and pyrite are present in nearly all of the veins; and in some veins pyrrhotite makes up a notable proportion of the sulfide minerals. Sphalerite and chalcopyrite are present as accessory minerals in nearly all the veins, and small amounts of tetrahedrite and native gold occur in many of them. The sulfide minerals and scheelite occur in shoots within the quartz veins. The principal gangue mineral is quartz with lesser amounts of calcite, ankerite, and barite. 
Scheelite in small, sparselymistributed crystals is known in a few deposits in the. Hyder district and in adjacent British Columbia outside the $1 \frac{1}{2}-b y$ 3-mile area described above. A little scheelite has been recognized in a vein on the Engineer group $2 /$ about 6 miles northwest of the Riverside mine. In British Columbia, between 4 and 6 miles southeast of the Mountain View property, scheelite has been recognized in two replacement deposits and in a quartz vein. containing tetrahedrite, all in rocks of the Hazelton group 3 .

\section{MINES AND PROSP ECTS}

Riverside mine

- The Riverside mine is 7 miles north of Fyder and on the east side of the Salmon River road. About a mile of underground workings are now accessible on three main. levels, of which about 2,300 feet are in the Iindeborg vein, the principal vein in the mine (see figs. 3 and 4). A mill, with a reported capacity in 1942 of nearly a ton per hour, and living accomodations for about 20 men are on the property.

\section{Production}

The following production data for the years 1925 and 1927 are from Geological Survey records. In 1925, 105 tons of concentrates of unreported grade were produced from ore mined from the Cross vein stopes. . In 1927 , 6,500 tons of ore were produced from the Eindeborg vein which yielded 390 tons of concentrates containing 59 percent of: lead, 39 ounces of: silver per ton, and 1:0,5 ounces of gold per. ton; scheelite was not recovered:

In 1941 the first scheelite concentrates were produced. The following production data have been kindly furnished by $\mathrm{Mr}$. J. H. Scott, present owner and operator of the mine. In $1941,3,368$ tons of ore were treated, from which were produced 30 tons of concentrates; containing 44 : percent of WO $_{3} \cdot$ In $1942,1,284$ tons of tailings from previous operations and 97 tons of mine ore were milled, yielding 36.6 tons of concentrates containing. 10.15 percent of: $\mathrm{WO}_{3}$.

\section{Geology}

The main geologic feature of the Riverside mine is the Iindeborg shear zone (see figs. 3, 4, and 5), an elongate, sheared inclusion of schist and argillite in the Texas Creek granodiorite. Tongues of the granodiorite have been intruded into the shear zone parallel to the schistosity. The zone strikes-N. 450 - 55\%:W. and dips steeply northward. It is exposed for about 2,000 feet along its strike and through a vertical interval of more than: 700 feet.

2/ Buddington, A. F., op. cit., p. 110.

3) Mathews, W. H., Dept. of Mines, British Columbia, personal communication. 
$\checkmark$ The Iindeborg shear zone is essentialliy a well-foliated schist inclusion along which some movement has taken place parallel to the foliation. The principal fault is now occupied by the Iindeborg vein; some movement has taken place along this fault since the emplacement of the vein.

The schistosity of the metamorphic rocks of the. Iindeborg shear zone is approximate ly parallel to the zone. The shear zone has within it no persistent stratigraphic or structural units other than the Iindeborg vein.

A granodiorite porphyry: dike and a smaller branch from it are exposed on the surface and in the underground workings, and are penetrated by some of the diamond-drill holes. The large main dike strikes about. N. $10^{\circ} \mathrm{W}$. and dips west (see figs.2 and 3). This dike probably cuts the Iindeborg vein a short distance southeast of the face of the thper "level drift (see fig. 5). The smaller branch dike strikes about $\mathrm{N} 40^{\circ} \mathrm{W}$. and dips steeply southward at the surface (see fig. 3). At depth it encounters the Iindeborg shear zone, where its dip is reversed to steeply northward parallel to the schistosity.

Thin lamprophyre dikes are common parallel to the schistosity of the shear zone. Nalchite dikes cut the shear zone approximately. in the middle of its exposed length (see figs. 2 and 4). post-mineral fault along the Iindeborg vein has displaced horizontally the malchite dikes about 20 feet (see figs. 3 and 4). The pitch of striations and the displacement of the dikes indicate that the hanging wall shifted about 28 feet, 45 degrees downward to the southeast. An attempt was made to trace this fault southeast of the malchite dikes along the vein, but within 100 feet the displacement is taken up along numerous small parallel faults, none of which could be traced more than 50 feet.

The Iindeborg shear zone contains the Iindeborg vein, which is not a single continuous vein but a mineralized zone containing discontinuous mineralized quartz veins and stringers. This: vein or mineralized zone is" generally nearer the footwall of the shear zone (see figs. 3 and 4), The vein in its leaner portions consists of pyritized schist or of quartz stringers'in a network as much as 6 feet wide with scattered grains of scheelite and sulfide minerals. The richer portions consist of a quartz vein up to 7 feet thick containing sulfide minorals and scheelite. Eelow an altitude of about 500 feet the Iindeborg vein splits dowaward (see sections, fig. 5). The separate veins below the split are narrower than the vein above.

other veins in the mine include the Cross and Ickis (sometimes called the Riverview) veins which are in Texas Creek granodiorite." The "Cross vein is exposed on the Mill level for 750 feet, and contains only rare scattered grains of scheelite. The Ickis vein, exposed in the Mill level for about 260 feet, contains a few scheelite crystals within 100 feet of the portal. The large, elongate mass of quartz as much as 60 feet thick exposed on the surface above the Upper level (sëe fig..3) is barren of scheelite and is probably later than the scheelite mineralization. 
Scheelite bodies

Three scheelite ore bodies, two of which are essentially mined out, are known in the Iindeborg vein. The largest ore body, the extent of which has been determined mainly by diamond-drilling, extends approximately 60 feet northwest and 90 feet southeast of the East raise on the Upper level (see fig. 5), and is believed to extend nearly 200 feet above and 100 feet below the level, The ore body dips northeastward, steepening from $50^{\circ}$ or $60^{\circ}$ at the top of the Bast raise to about $70^{\circ}$ at the floor of the Upper level, and appears to rake southeastward. It is here called the East ore body, in accordance with the usage of the Bureau of Mines. Judging from the exposures in the Upper level, the East raise, and from the diamond-drili cores, both scheelite and galena are more abundant in the upper part of the ore body, 50 to 150 feet above the Upper level. The outine of the Fast ore body show in fig. 5 contains some barren portions, and the vein within this body ranges in thickness from about half a foot to slightly more than 7 feet.

A second ore body, which was opened by the Footwall, Hanging-wall, and Intermediate level stopes (see fig. 5), was nearly mined-out during 1941: The lean margin of this ore body is partly exposed between the Intermediate level and the Hanging-wall stopes and in the back of the Intermediate level stope. (see fig. 5). Fifteen feet above the Intermediate level the ore body splits downward, (see section $B-B$ !, fig. 5). It is reported that the quartz vein was 2 to 3 feet thick at the Intermediate level and thinned to about 1 foot in the Footwall and Hanging-wall stopes. In several large specimens of the mined-out vein the scheelite is segregated in a nearly solid band, 2 to 4 inches thick; in quartz.

The ore that was removed from the Overhead and Underhand stopes near the face of the Northwest drift, and the ore now assumed to be present beneath the Underhand stope is referred to as the West ore body (see section A-A', fig. 5), in accordance with Bureau of Mines lisage. The ore body is a white vitreous quartz vein containing large crystals of scheelite, pyrite, and barite, up to several inches across. The vein is from one-half to $3 \frac{1}{2}$ feet thick but has an average thickness of $2 \frac{1}{2}$ feet. It extends for 33 feet in the "bottom of the Underhand stope and is exposed for several more feet to the northwest in the Northwest drift. This ore body is believed to have little depth because drill hole SI encountered no scheelite 50 feet below the ore body and because similar scheelite bodies in white vitreous quartz veins in the Bureau of Mines raise, in the No. 3 stope, and elsewhere in the mine are small.

In addition to the three principal known scheelite-bearing bodies it is probable that the ore mined in 1927 from the large stope above the Northwest drift (see fig. 5) contained considerable scheelite, Scheelite-bearing quartz is exposed in many places about the margins of the stope. It has been reported that a heavy white mineral, presumably scheelite, appeared on the mill tables in 1927, but it was not recovered.

On the surface at an altitude of approximately 950 feet the Iindeborg vein has been almost completely exposed for a distance of 125 feet by three open cuts along the vein (see figs. 3 and 5). The vein is from 2 to 3 feet thick. It contains scattered grains of scheelite and a band of solid galena as much as 3 inches thick. 


\section{Reserves}

Considerable information is avallable for estimating the reserves in the Riverside mine, The Bureau of Mines took 52 channel samples on the Iindeborg vein, drilled 41 diamond-drill holes, and drove a raise 15 feet on the Upper level:

The diamond-drilling consisted of 37 holes started from underground stations and 4 holes started from stations on the surface, totalling 4,660 feet. Analyses were made of 36 samples of scheelite-bearing arill cores and 47 siudge samples: In most of the arill holes the core recovery was 95 percent or better; sludge analyses which are lower than. the corresponding core analyses are.not considered in the computations of grade in this report. Core has lost in three arill holes (holes M2, M32, and M34) and sludge analyses from these holes are included. The Bureau of Nines data are supplemented by four analyses of channel samples taken by the Geological survey. The location and $\mathrm{WO}_{3}$ content of the samples are shown on figure:5. The data from the drill-cores obtained by the Bureau of Mines are summarized in table 1. For convenience the holes are listed numerically. The cores of 16 holes contain no scheelite and these holes are omitted from table 1.

Corés from drill holes S3 and MI8 were also analyzed for other metals; and the data furnished the Seological Survey by the Bureau of Mines. The following are composite figures:

Drill hole $\begin{gathered}\text { Iead } \\ \text { (percent) }\end{gathered} \begin{gathered}\text { Copper } \\ \text { (percent) }\end{gathered}$ (ounces per ton) (ounces per ton)

S3 4.05 no report no report
M18
4.58 none no report

The calculated average $\mathrm{WO}_{3}$ content of selected parts of the ore bodies is shown on figure 5 by bracketing the samples included in the average.

For the estimation of reserves, material arbitrarily is considerea ore if the product of percent of "WO times the thickness in feet is 0.5 or more." The minimum grade used for calculation, however, is 0.2 percent of $\mathrm{WO}_{3}$ ir respective of thickness. Thus 1 foot of material conteining 0.5 percent of $\mathrm{WO}_{3}$ or 2 feet of material containine 0.25 percent of $\mathrm{WO}_{3}$ is considered ore.

The data from which the grade and tonnage of the Hast ore body are estimated are shown on section $D-D^{\prime}$, figure 5. Cat-of points, as defined above, were determined by graphic interpolation where data are available and indicate a roughly elliptical ore body on which the reserve estimates are based. Because the grade ranges widely and abruptiy, and because the data, though numerous, are not well-distributed throughout the ore body", it" is believed that only a generalized statement of grade is justified. 
Table 1

Drill Depth of sample Distance Percent Total. Estimated Calculated Weighted hole in hale (feet) sampled of $\mathrm{WO}_{3}$ sampled angle, vein average number (feet) footage hole to

thickness percent vein

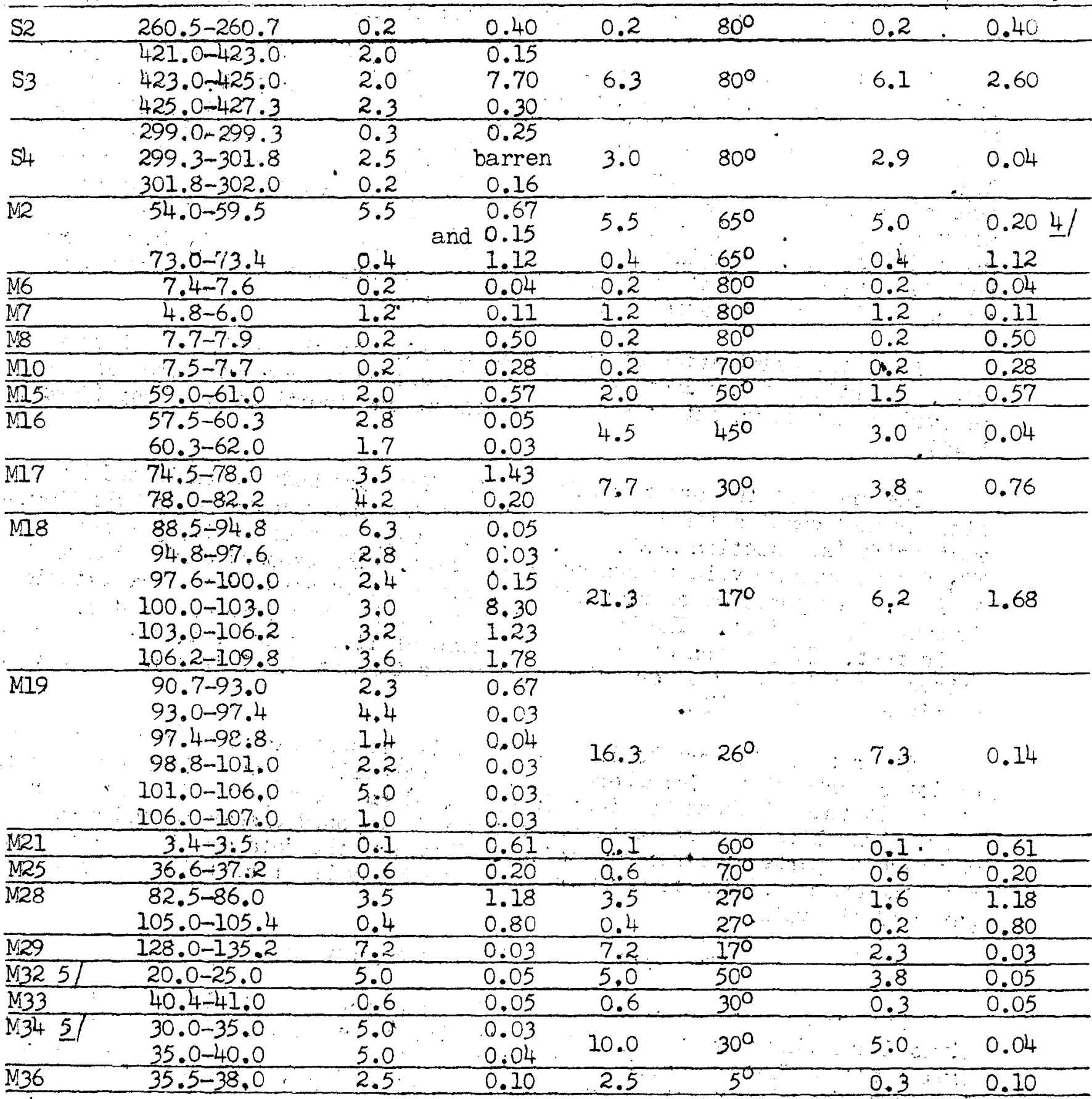

4/ Combined core and sludge analysis.

5) Sludge analysis 
The ore above the Upper level contains, according to a weighted average, slightly more than 1 percent of $\mathrm{WO}_{3}$. "and ore below the Upper level averages slightly less than 1 percent of $w_{3}$. An average grade of about 1 percent of $\mathrm{WO}_{3}$ is indicated for the entire body as outlined on Section D-D'. The average thickness of the upper one-third of the body is slightly greater than 4 feet; near the low-grade margins the average thickness is little more than 2

. feet. . An average thickness of about- $3 \frac{1}{2}$-feet is indicated for the entire body,

The outlined ore body has an a ea about 32,000 square feet measured on the vein surface, and a volume of about 112,000 cubic feet. Using a tonnage factor of 11.5 cubic feet to a ton, the st ore body originally contained.about 9,700 tons of ore, with an averag'e grade of about 1 percent of W3. This tonnage is classed here as indicated ore. About 650 tons have. been mined out (as of 1943). so that the present (1943) reserves aggregate about 9,000 tons. This tonnage contains about 9,000 units (20 pounds equal one unit) of $W_{3}$. Considerable barrén ground probably lies with in the ore body as outlined, but it is likely that barren portions are compensated by ore which is near but outside the Iimits shown.

Sinee the examination of the Riverside mine by the Geological Survey in 1943, a portion of the Fast ore body has been mined. How much ore has been removed is not known but it may be as much as one fourth of the body (January 1945).

The grade of the ore remaining in the West ore body is indicated by nine channel samples taken in the bottom of the Underhand stope of the Northwest drift (see section $A-A^{\prime}$, fig. 5). The samples average 1.3 percent of $\mathrm{WO}_{3}$ for an average vein thickness of 2.4 feet. "The exposed strike length is

- 36 feet: For purposes of claculating tonnage it is assumed the ore extends downward for 20 feet. The body outlined above has a volume of about 1,700 cubic feet. If one ton of ore has a volume of 11.5 cubic feet, the body comprises about 150 tons of ore classed here as indicated. This tonnage contains nearly 200 units of $\mathrm{WO}_{3}$.

Other scheelite ore bodies are probably présent elsewhere within the unexplored parts of the Lindeborg vein. The scheelite exposed in the open cuts at an altitude of about 950 feet (see fig. 5) maty be a part of a buried ore "body. Scheelite-bearing portions of the vein exposed elsewhere underground maty also be parts of other ore bodies. However, the data are too few to estimate the amount of inferred tungsten ore that may be present in the unexplored parts of the vein.

\section{Suggestions for further exploration.}

The ground between the Upper level and the surface could be tested by diamord-drilling from the surface on the hanging-hall side of the vein. Several thousand feet of drilling, involving holes up to several hundred feet Iong spaced to intersect the vein at appropriate intervals would be necessary. 
Nountain View mine

The Nountain View mine is $5 \frac{1}{2}$ miles north of Fyder between Fish and Skookum creeks (see fig. 2). Buildings on the property consist of a bunkhouse for 12 men, a waterwheel power house, and several small sheds for storing equipment.

\section{Geology}

The property which includes several known veins, has been described by Euddington 6/, who recognized scheelite in one of the veins. From 1925 to 1929 a total of 3,600 feet of tunnels were driven at the Mountain View mine. of these workings, 3,500 feet are on the Skookum tunnel level at an altitude of 540 feet (see fig. 6). No ore has been produced from the mine...

The mine is principally in Texas Creek granodiorite, a few hundred feet west of the main body of rocks of the Hazeltion group (see fig. 2). The only vein on the property. known to contain scheelite is the Fish Creek No. 2 or "Gray Copper" vein (see fig. 6). This vein, which cuts the Texas Creek granodiorite, strikes $\mathrm{N} .450 \mathrm{~W}$ and dips $50^{\circ} \mathrm{N}$. The vein is exposed on the surface for 480 feet by several open cuts, and underground by a 50-foot shaft and a 60-foot drift in a short adit. In the Skookum tumiel the vein is exposed for a horizontal distance of 240 feet (as of October 1, 1944). Pits dug on the surface along the projected trend of the vein to the southeast do not reach bedrock.

The princlpal ore minerals in the Fish Creek No..2 vein are pyrite, pyrrhotite, and scheelite with some chalcopyrite, galena, and a little sphalerite, tetrahedrite, and freibergite, The gangue minerals are quartz with much lesser amounts of barite. The vein also carries some gold and silver.

\section{Reserves}

In 1942 the Bureau of Mines took 15 channel sampies underground on the Fish Creek No. 2 ("Gray Copper") vein of the Mountain View mine. One sample was collected by the Geological Survey... The location and $\mathrm{WO}_{3}$ content of the samples are shown on figure 6. The weighted average of 12 channel samples taken in the Skookum tunnel drift and representing a strike Iength of 45 feet and an average thickmess of 1.3 feet is about 1 percent of $\mathrm{NO}_{3}$

6) Buddington, A. F, op. cit, , pp. $63-67$. 
Four samples were taken in 1942 by the Bureau of Mines from the short adit 300 feet above the Skookum timmel drift (see fig. 6). On the bas is of examination with the ultraviolet lamp, the better portions of the vein in the Skookum tunnel. drift are believed to contain more scheelite than the vein in the short arift above, although the WO $_{3}$ analyses do not support this observation. Three of the four samples taken in the short drift are believed to show too high a $\mathrm{WO}_{3}$ content to be considered representative of an average for this drift. Apparently the samples were taken on the richest parts of the vein. The $\mathrm{WO}_{3}$ content of the vein in this drift is estimated to be about 0.5 percent. .

In 1944 the Bureau of Mines extended the Northwest drift of the Skookum tunne1. On October 1, the drift had been extended for 130 feet. The Bureau of Mines has carefully sampled the new vein exposures, but the analytical results are not yet available. However, on the basis of examination with the ultraviolet lamp, it appeared" that the better portions of the vein are exposed in the old drift and that the average grade in the extended part of the drift will average less than 1 percent: of $\mathrm{WO}_{3}$

The ore exposed in the Skookum tunnel drift forms the basis for estimating a small volume of indicated ore... The main ore-bearing portion of the vein averages about 1.3 feet wide and is about 90 feet long. Assuming it extends 30 feet up and 30 feet down the dip of the vein, approximately 600 tons of ore, c ntaining about 1 percent of " $\mathrm{wO}_{3}$ are indicated.

Additional reserves may be inferred elsewhere in the Fish Creek No. 2 vein. A small proportion of the additional reserves can be considered as indicated ore, for example, the ore exposed in the surface cuts and shallow workings and the scheelite-bearing portions of the vein northwest and southeast of the main ore-bearing part of the vein in the Skookum tunnel drift. The Skookum tunnel drift is approximately 400 feet down the dip of the vein from the surface, Within this interval is a large unprospected portion of the vein and it is probable that some of the vein contains sufficient scheelite to be classed as ore.

\section{Fi sh Creek Property}

On the Fish Creek group of claims along the east bank of Skookum Creek (see fig. 2) two veins in Texas Creek granodiorite near the Hazelton rocks, contain sparse scheelite. At an altitude of about 1,600 feet an adit known as adit No. 3 has been driven southeastward for 60 feet on a quartz vein that strikes $N_{0}, 35^{\circ} \mathrm{W}$. and dips $65^{\circ} \mathrm{N}$. The vein is 4 feet thick at the adit portal but splits into a network of quartz stringers about 20 feet from the portal and pinches out 10 feet above it. Scheelite occurs as scattered small crystals in the quartz for 40 feet along the drift. The vein is estimated to contain less than 0.1 percent of $\mathrm{WO}_{3}$. 
According to Buddington: I/

"....about 350 feet northeast of this vein..... is another vein; which has been prospected by three adits (Nos. 4, 5, and 6) at altitudes of about $1,930,1,900$, and 1,800 feet, with lengths of $60,109^{\circ}$, and 185 feet, respectively. The vein strikes N. $50^{\circ}$ W. and dips $45^{\circ}-50^{\circ} \mathrm{NE}$. Its width at the portals of the three adits is 19,24 , and 15 inches. A raise connects the middle and upper adits, and the vein has been partly stoped for: 30 feet above the upper adit. In these workings it ayerages less than a foot in. thickness but contains shoots of ore up to the full width."

The visible sulphides comprise salena and pyrite with tetrahedrite, sphalerite, and a little chalcopyrite."

The adits aremostly in granodiorite, but; near their faces a fault separates the granodiorite from rocks of the Hazelton group and cuts off the veins. Minor amounts of scheelite are present in the vein in all of the adits. Adits No. 4 and No. 6 contain only sparse grains, but adit No. 5 contains a 3-inch quartz-scheelite stringer next to a quartz-sulfide vein. In the first 40 feet of adit No. 5 about 20 feet of this stringer is estimated to contain from 1 to 2 percent of $\mathrm{WO}_{3}$. The scheelite is in distinct crystals as much as I inch across. From 40 to 80 feet from the portal the scheelite is sparse, and the stringer probably contains less than 0.1 percent of $\mathrm{WO}_{3}$.

\section{Iast Chance prospect}

The Iast Chance prospect (see fig. 2) is on the ridge between Skookum Creek and Salmon River at an altitude between 2,600 and 2,900 feet and approximately 1 mile east of the Riverside mine. The Iast Chance claims, formerly known as the Olympia Extension claims, are described by Buddington 8/. The underground workings comprise 700 feet of tunnels, a 50-foot raise, and two 50-foot winzes. The winzes are now filled wi th waste rock.

The vein, known as the Olympia Extension vein, has been traced on the surface for several hundred feet by a series of open cuts and is exposed underground for a total distance of 180 feet along the strike in two drifts 25 feet and 75 feet below the outcrop and 90 . feet and 100 feet long respectively. The east end of the upper drift and the west end of the lower drift are connected by the 50-foot raise. The vein in the lower drift averages $I$ foot thick and contains sparsely distributed grains of scheelite for a length of 50 feet; " the grade of this part of the vein is estimated, to be

7) Buddington, A. F., op. cit., p. 69.

8) Buddington, A. F., op. cit. pp. 69-71. 
about 0.05 percent of $\mathrm{WO}_{3}$. In the upper drift and on the surface above the upper drift the vein is 3 to 4 feet thick and is well mineralized with galena, tetrahedrite, chalcopyrite, and sphalerite." Several small crystals of scheelite were seen in the upper drift, but examination of the surface cuts with the ultraviolet lamp falled to reveal any scheelite.

\section{Monarch prospect}

A 30-foot drift on the Monarch group of claims, has exposed a quartz veinlet containing scheelite. The veinlet may be part of the Olympia Extension vein that crops out 1,000 feet to the southeast. The veinlet, which averages 4 inches in thickness, is exposed in the face and along the arift except for an interval 10 feet from the face, where it is absent. The veinlet is estimated to contain from 0.5 to 3.0 percent of $\mathrm{WO}_{3}$ throughout its exposed length. A surface cut on a fissured zone above the drift failed to show any scheelite when examined wi th the ultraviolet lamp.

\section{Bluebird prospect}

In October 1942, the Bluebira claim (see fig. 2) was located by Arthur. O. Moa. The vein was not examined by the author. It is reported to be in - Texas Creek granodiorite about 1,500 feet west of rocks belonging to the Hazelton group and at an altitude of about 2,300 feet. According to Mr. Moa, the vein is exposed for only a few feet in a creek bottom and is 4 inches wide. It contains molybdenite along its walls, and quartz with sparsely disseminated pyrite, chalcopyrite, galena, and scheelite in the central portion. Three hand specimens of the vein were estimated by the writer to contain about 0.5 percent of $\mathrm{WO}_{3}$.

\section{Other properties}

Scheelite in rare grains was observed on the Brigadier (Hyder Butte), Iiverty, Bear (Iucky Boy Bxtension), Alaska Premier (south workings only), and Eng,ineer properties. The Engineer property is outside the area shown in fig. 2, Search with an ultraviolet lamp failed to reveal scheelite on the Iast Shot, Helen (Howard). Six Mile, Cantu, Hyder Skookum, Titan, Cripple Creek, Daly-Alaska, 96, Texas Discovery, Hyder Iead, Morning, Iake, Blasher, Edelweiss, and Jumbo properties. Nany of these properties are outside the area shown in fig. 2 .

\section{SUMNAIYY OF RESERVES -}

Scheelite has been observed in veins on 11 properties in the Hyder district. Only the Riverside mine and the Mountain View mine are known to contain scheelite-bearing rock in sufficient quantity and of sufficiently high grade to constitute ore reserves.. 
The Riverside mine is estimated to contain about 9,000 tons of indicated ore (from this should be subtracted ore mined from the Bast ore body since early 1943), averaging about one percent of $\mathrm{WO}_{3}$. The Mountain View mine is estimated to contain about 600 tons of indicated ore of similar grade.

Additional ore reserves are probably present in the unprospected parts of the veins at both the Riverside mine and the Mountain View mine, but not enough development work has been done to estimate quantitatively their size and grade.

January 1945 

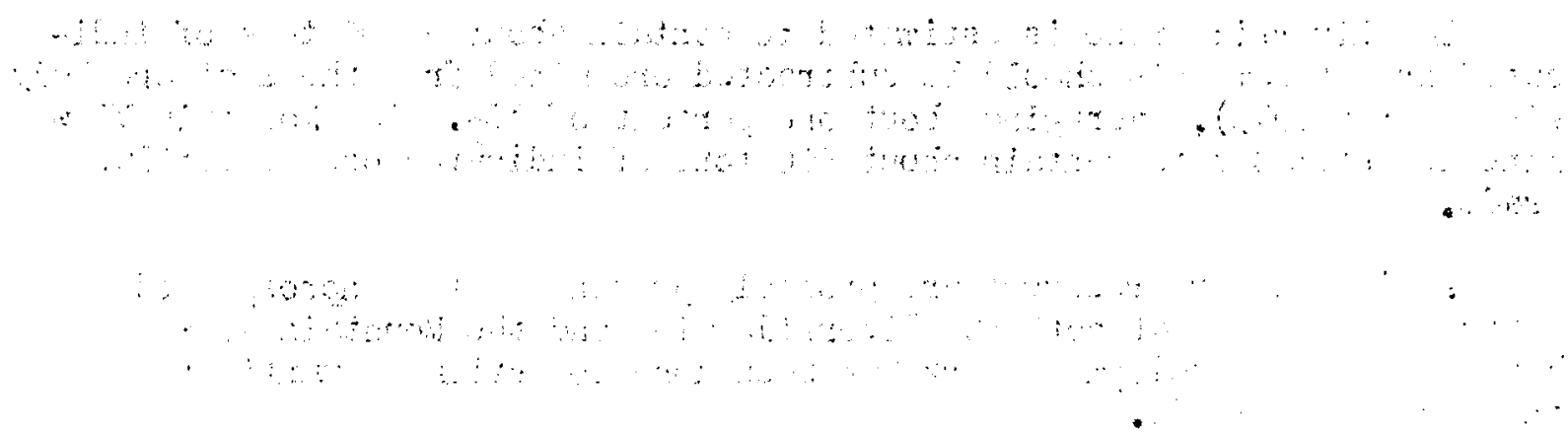